\title{
Isolation and Identification of Endophytic Fungi from Srikaya Plants (Annona squamosa) Having Potential Secondary Metabolites as Anti-Breast Cancer Activity
}

\author{
PRASETYAWAN YUNIANTO ${ }^{1,3 *}$, SYOFI ROSMALAWATI ${ }^{2}$, INDRA RACHMAWATI ${ }^{2}$, \\ WAHYUDI PRIYONO SUWARSO ${ }^{3}$, AND WAHONO SUMARYONO ${ }^{1}$
}

\author{
${ }^{1}$ Center for Pharmaceutical and Medical Technology, BPPT, \\ BPPT Building II 15 th floor, Jalan MH Thamrin 8, Jakarta 10340, Indonesia \\ ${ }^{2}$ Biotechnology Research Center, BPPT, PUSPIPTEK Building 630, Serpong, Tangerang Selatan 15314, Indonesia \\ ${ }^{3}$ Department of Chemistry, Faculty of Mathematics and Natural Science, Universitas Indonesia, Depok 16424, Indonesia
}

\begin{abstract}
Annonaceous acetogenin was extracted from Annona squamosa (Srikaya) seeds. It has cytotoxic activity against cancer cells and lower toxicity compared to other cancer drugs. Endophyte from Annonaceae is expected to have similar extracted metabolites to the host, thus increasing the economic value. This research is a preliminary study to obtain active compounds with potential as anti-cancer agents from endophytic fungi of Srikaya plants. Four endophytic fungal strains were isolated from Srikaya plants (Annona squamosa) and identified based on 28S rDNA sequence. The isolates are SKY II.3.1, SKY I.1.2, SKY II.3.2, and SKY III.3.1, and have similarity with Fusarium sp. Vega760, Fusarium sp. NRRL 22354 NRRL223, Nectria rigidiuscula, and Fusarium sp. BOL35, respectively. The identified isolates were fermented in liquid media for three weeks. The liquid and mycelium were extracted using ethyl acetate. Whole extract of each fermented isolate was partitioned and evaporated to obtain ethyl acetate extract. Cytotoxicity assay of ethyl acetate extract was carried out at level 100 ppm by Methyl Thyazole Tetrazolium (MTT) viability test towards MCF-7 (breast cancer cell). The result indicated that each ethyl acetate extract could inhibit the viability of cell MCF-7 with $11.34 \%, 99.78 \%, 91.48 \%$, and $96.84 \%$, for SKY II.3.1, SKY I.1.2, SKY II.3.2, and SKY III.3.1 respectively. Based on the results of cytotoxicity assay on MCF-7 breast cancer cells, endophytic fungi isolates SKY I.1.2, SKY II.3.2, and SKY III.3.1 are potential as sources of anti-breast cancer compounds.
\end{abstract}

Key words: 28S rDNA, Annona squamosa, endophytic fungi, MTT viability test

Senyawa acetogenin yang diekstrak dari biji srikaya menunjukkan potensi sitotoksik terhadap sel kanker, dan toksisitasnya lebih rendah dibandingkan dengan obat kanker lainnya. Endofit dari srikaya diharapkan memiliki metabolit yang sama dengan senyawa hasil ekstraksi dari inangnya, sehingga lebih ekonomis daripada mengekstraksi dari bijinya. Penelitian ini merupakan studi pendahuluan untuk mendapatkan senyawa aktif yang mempunyai potensi sebagai anti kanker yang berasal dari metabolit sekunder jamur endofit tanaman Srikaya. Empat galur jamur endofit telah berhasil diisolasi dari tanaman srikaya (Annona squamosa) dan diidentifikasi secara genetik menggunakan metode 28S rDNA. Hasil identifikasi menunjukkan bahwa isolat jamur SKY II.3.1, SKY I.1.2, SKY II.3.2, dan SKY III.3.1 mempunyai kemiripan tinggi dengan masing-masing Fusarium sp. Vega760, Fusarium sp. NRRL 22354 NRRL223, Nectria rigidiuscula, dan Fusarium sp. BOL35. Selanjutnya empat isolat jamur tersebut difermentasi dalam media cair selama tiga minggu, dan dilakukan ekstraksi baik terhadap media cair maupun miseliumnya dengan menggunakan etil asetat. Hasil ekstraksi dari masing-masing isolat, dipekatkan dan dipisahkan lebih lanjut, sehingga dihasilkan ekstrak etil asetat. Uji sitotoksisitas ekstrak etil asetat dilakukan masing-masing dengan konsetrasi 100 ppm mengunakan metode Methyl Thyazole Tetrazolium secara viabilitas pada sel kanker payudara MCF-7. Hasilnya menunjukkan bahwa ekstrak etil asetat dari masing-masing isolat secara berurutan dapat menghambat pertumbuhan sel MCF-7 sebesar 11,34\%, 99,78\%, 91,48\%, dan 96,84\%. Berdasarkan seleksi dengan uji sitotoksisitas terhadap sel MCF7, maka yang layak untuk dilakukan fermentesi lebih lanjut untuk mendapatkan senyawa anti kanker payudara adalah isolat jamur SKY I.1.2, SKY II.3.2, dan SKY III.3.1.

Kata Kunci : 28S rDNA, Annona squamosa, jamur endofit, uji MTT

Endophytic microbes are bacteria or fungi that live in plant tissue for a certain time period, forming colonies without harming its host. Many higher plants may contain several endophytic microbes capable of producing secondary metabolites. It is allegedly a result

*Corresponding author; Phone: +62-21-7560536, Fax: +62-21-7566922; E-mail: pyunianto@gmail.com of co-evolution or genetic transfer between the host plant and the endophytes, which is highly dependent on environmental conditions where the host lives (Tan and Zou 2001). Bioactive natural compounds produced by endophytes have promising potential applicability in medicine, agriculture, and industry (Joseph and Priya 2011).

Million dollars have been generated after the first 
discovery of Taxol (paclitaxel) as an anti-cancer drug that endophytic fungi isolated from the plant Taxus brevifolia Nutt (Wani et al. 1971). Currently, several other endophytic species have been isolated from various Taxus species such as Taxus baccata, T. Cuspidata Sieb. The compounds also show efficacy as anti-tumor (Strobel and Daisy 2003).

Srikaya also called sugar apple or sweetsop (Annona squamosa) one of the known species of Annona fruits. Based on ethnobotanical experience, part of the sugar apple in the form of roots, leaves, seeds, and bark have been utilized as traditional medicine for efficacious anti-inflammatory, antidepressant, astringent, laxative to treat intestinal worms cases (anthelmintic), abortivum, insecticide, and tonic. This plant contains alkaloids, generally of asporfin type (anonaine) and bisbenziltetrahydroisoquinoline (reticuline). The seeds contains derivatives of polyketide bistetrahydrofuran; acetogenin (squamostatin $\mathrm{C}, \mathrm{D}$, anonaine, annonacine A, anonin 1, IV, VI, VIII, IX, XVI, squarnostatin A, bulatacin, bulatacinon, squamon, neoanonin $\mathrm{B}$, neo desacetylluraricin, neo reticulacin $\mathrm{A}$, squamosten $\mathrm{A}$, asmicin, squamocin, annonacine, anonastatin, and neoanonin) (Wu 2007; Hai et al. 2003).

According to Landolt et al.(1995) annonaceae acetogenin is a new compound and natural material having potential activity as antitumor, pesticide, and bioactive that can act as a barrier to electron transport in mitochondria (Mclaughin and David 2001). Chih and Yang (2008) found a new compound that have a cytotoxic potential against cancer cells. It is a derivative of mono-tetrahydrofuran (THF), an Annonaceae type acetogenin extracted from sugar apple seeds.

Research concerning Annonaceous acetogenin as anticancer drug is still being carried out in the United States pharmaceutical industry. According to Hollingworth et al. (1994), Up-John Corporation has conducted in vivo testing of annonaceous acetogenin compounds and the results showed that they were active against mice L-1210 leukemia. Therefore, annonaceous acetogenin has a greater potential than Taxol due to its low toxicity.

Cancer's prevalence tends to increase from time to time. According to an estimation by Globocan IARC, in 2002 the breast cancer incidence was 26 per 100000 women and cervical cancer was 16 per 100000 women (Karrosi et al. 2009). Thus new drugs from natural resources such as plants or their endophytic microbes are still required.
Endophytes from Annonaceae is predicted to contain similar metabolites as those extracted from the host, so it is expected that the extraction from the endophytes is more economical than extraction from the seeds of the host fruit. This research is a preliminary study to obtain active compounds potential as anticancer from endophytic fungi of sugar apple plants. We screened endophytic fungi from sugar apple plants as potential anti-cancer based on the observation of viability of breast cancer cells (MCF-7) using in vitro assay with MTT method. The potential fungi were isolated and identified using $28 \mathrm{~S}$ rDNA.

\section{MATERIALS AND METHODS}

Isolation of Endophytic Fungi. Twigs of sugar apple plants from Tangerang, Banten, Indonesia, were washed with distilled water, cut into $1-2 \mathrm{~cm}$. The surface was sterilized by three times immersion, first in ethanol $70 \% \mathrm{v} \mathrm{v}^{-1}$ for $1 \mathrm{~min}$, second in $5.25 \% \mathrm{NaOCl}$ solution for $5 \mathrm{~min}$ and the last, in $70 \%$ ethanol solution $\mathrm{v} \mathrm{v}^{-1}$ for $0.5 \mathrm{~min}$. The outer skin is discarded with a sterile knife and placed on an agar medium in a petri dish containing dried host plant leaves and antibiotics. The media composition was $15 \mathrm{~g}$ agar, $15 \mathrm{~g}$ dry powder of the host plant leaves, $0.2 \mathrm{~g}$ chloramphenicol, and up to 1 Ldistilled water (Rusman 2006).

Incubation was carried out at room temperature for 1-3 weeks depending on the fungal growth rate. The fungal colony then moved to a new media with the composition of $15 \mathrm{~g}$ agar, $15 \mathrm{~g}$ Malt extract, and up to 1 L of distilled water, and adjusted to $\mathrm{pH} 7.4$ to 7.8.

Liquid Fermentation of Isolated Fungi. A single isolate of endophytic fungus (the macroscopic and microscopic) is used as mother culture for cultivation. This isolate was incubated for 3 to 7 days before being used as inoculums of the starter for the subsequent cultivation or fermentation.

Liquid fermentation was carried out in $150 \mathrm{~mL}$ of Wickerham medium (1 L of distilled water consisted of $3 \mathrm{~g}$ yeast extract, $3 \mathrm{~g}$ Malt extract, $5 \mathrm{~g}$ peptone, $20 \mathrm{~g}$ glucose monohydrate, with $\mathrm{pH} 7.2$ to 7.4 ) in $300 \mathrm{~mL}$ Erlenmeyer flask of the culture surface at room temperature, between 14-21 d (Ebel et al. 2006), with amount of starter about $5 \% \mathrm{~V} \mathrm{v}^{-1}$.

Ethyl Acetate Extracts Preparation. A $250 \mathrm{~mL}$ Ethyl acetate was added into each fungal culture in an erlenmeyer flask and the mixture was kept overnight to ensure that the fungal cells died. The mixture was then sonicated three times for 15 minutes (for cell destruction) and then filtered using Büchner vacuum. 
The ethyl acetate phase was then separated from water phase (medium) using separation funnel. To remove the remaining salts and other polar constituents, the ethyl acetate phase was washed with water two times. Just after evaporation, the ethyl acetate extracts was diluted in $90 \%$ methanol and extracted with $n$-hexane to remove fatty acids and other non-polar constituents. After that the methanol phase was evaporated. At the same time, the water phase (medium) was extracted with water-saturated nButanol to collect the polar constituents.

DNA Isolation. Fungal DNA isolation and purification was performed using PrepMan ${ }^{\circledR}$ Ultra Sample Preparation Reagen from Applied Biosystems ${ }^{\circledR}$. The edge of filamentous fungus colony from a culture plate was suspended in $100 \mu \mathrm{L}$ of PrepMan Ultra Sample Preparation Reagent in microcentifuge tube. The sample was heated in heat block for $10 \mathrm{~min}$ at $100{ }^{\circ} \mathrm{C}$ and then cooled at room temperature for $2 \mathrm{~min}$. After centrifugation at $15000 \mathrm{xg}$ for $2 \mathrm{~min}$, supernatant was ready for PCR.

PCR Amplication and DNA Sequencing. The DNA isolated from pure fungal isolates was then used as a template for PCR amplification of the $28 \mathrm{~S}$ ribosomal gene using the universal fungal primers NL1 and NL4 (O'Donnell 1993; Ainslie and Cameron 2007). The PCR was carried out using TaKaRa LA Taq ${ }^{\mathrm{TM}}$ from TAKARA BIO Inc. contains TaKaRa LA Taq ${ }^{\mathrm{TM}}$ DNA Polymerase, PCR buffer (with $\mathrm{MgCl}_{2}$ ) and dNTPs. Primer NL1 (5'-GCATATCAATAAGCGGAGGAAA AG-3') and NL 4 (5'-GGTCCGTGTTTCAAGACGG-

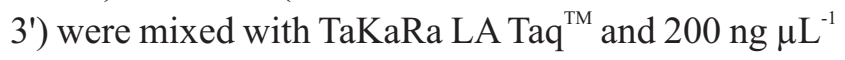
DNA template.

The PCR reaction was the performed using the following program: initial denaturation for $2 \mathrm{~min}$ at $98^{\circ} \mathrm{C}$, followed by 30 cycles of amplification (denaturation for $20 \mathrm{~s}$ at $98^{\circ} \mathrm{C}$, annealing for $20 \mathrm{~s}$ at $52^{\circ} \mathrm{C}$, and extension for 2 min at $72{ }^{\circ} \mathrm{C}$ ) and final extension of $4 \min$ at $72^{\circ} \mathrm{C}$. The PCR products were gel electrophoresed in $1 \%$ AgaroseGel-Electrophoresis for $25 \mathrm{~min}$ in TAE buffer. The agarose gel was then stained using $1 \%$ Sybr Safe (Invitrogen). A 600 bp stained DNA fragment was then excised from the agarose gel and then purified using Geneaid Gel Extraction Kit.

The amplified fungal DNA was then submitted for sequencing using Genetic Analyzer 3130. The sequencing cycle was performed as follows: initial denaturation at $96{ }^{\circ} \mathrm{C}$ for $3 \mathrm{~min}, 25$ reaction cycles (denaturation for $10 \mathrm{~s}$ at $96^{\circ} \mathrm{C}$, annealing for $5 \mathrm{~s}$ at $50^{\circ} \mathrm{C}$, and extension for 4 minutes at $60{ }^{\circ} \mathrm{C}$ ). NL1 and NL4 primers were used for sense and antisense sequencing, respectively. Then, DNA sequence allignment was performed using ClustaIX. The phylogenetic tree was constructed by comparing the base sequences to the data in Genebank with a help of Blast-Algorithmus and visualized using Tree View 1.6.6.

Cytotoxicity Test in vitro with Methyl Thyazole Tetrazolium (MTT) Assay. The ethyl acetate extract fraction was tested in vitro for its cytotoxicity against cancer cells using MCF-7 cell line (breast cancer cell line) using MTT assay based on the protocol from Cancer Chemoprevention Research center, Universitas Gajahmada.

The MTT assay is commonly used to evaluate cell survival, based on the ability of viable cells to convert MTT, a soluble tetrazolium salt [3-(4,5-dimethylthyazole-2-yl)-2,5 diphenyl-tetrazolium bromide], into an insoluble formazan precipitate, which is quantified by spectrophotometry. MCF-7 cell was treated by each ethyl acetate extract with concentration $100 \mathrm{ppm}(\mu \mathrm{g}$ $\left.\mathrm{mL}^{-1}\right)$ in 96-well tissue culture dishes and incubated with MTT ( $\left.5 \mathrm{mg} \mathrm{mL}^{-1}\right)$ for $4 \mathrm{~h}$. MCF-7 cells not treated by the extract was used as a control. The cells were then solubilized in $100 \mu \mathrm{L}$ of DMSO. The amount of MTT dye reduction was calculated based on its absorbance at $570 \mathrm{~nm}$. Cell viability in treated cells was expressed as the amount of dye reduction relative to that of untreated control cells. The wells which contained only medium and $10 \mathrm{~mL}$ of MTT were used as blanks for the plate reader.

\section{RESULTS}

Isolation of Endophytic Fungi. Four endophytic fungi were isolated from srikaya plants (Annona squamosa L.). Isolations of the fungi were performed based on observation on macrocospic and microscopic level. The fungal isolates show different morphological characteristic (Table 1 and Fig 1).

PCR Amplification and Identification of Endophytic Fungus. The 28S rDNA regions were amplified using the universal fungal primers NL1 and NL4 and isolated DNA as templates by for. As

Table 1 The morphology of endophytic fungi isolated from the twigs of sugar apple on agar plate with media PDA

\begin{tabular}{cc}
\hline Isolat Code & Color and form of colonies on agar plate \\
\hline SKY II.3.2 & Redish, smooth \\
SKY III.3.1 & White, coarse \\
SKY I.1.2 & White- yellowish, \\
SKY II.3.1 & White, smooth \\
\hline
\end{tabular}




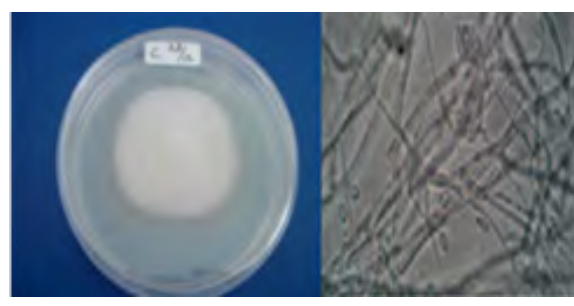

III.3.1

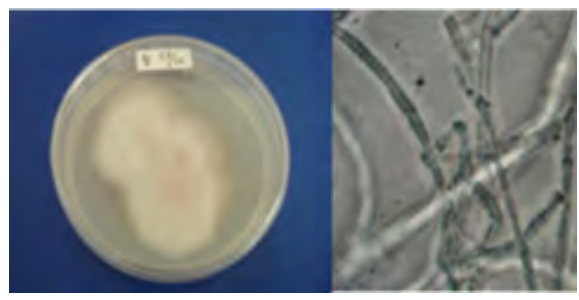

I.1.2

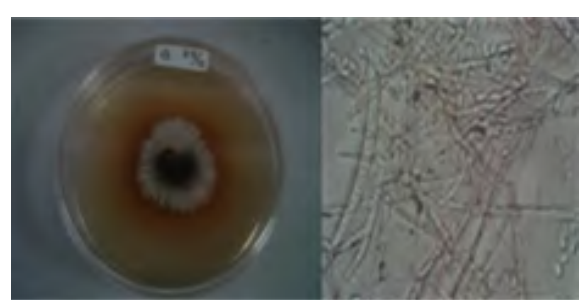

II.3.2

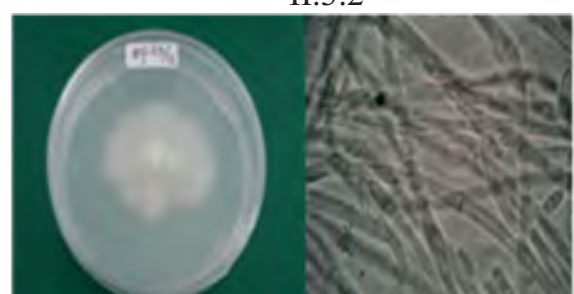

II.3.1

Fig 1 Morphology isolates of endophytic fungi from twig sugar apple (Annona squamosa).

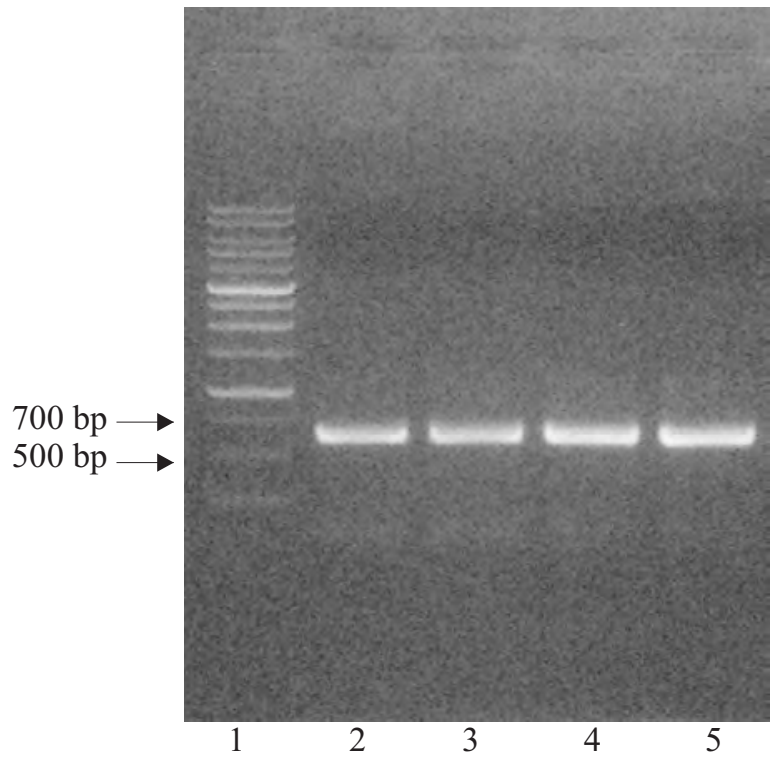

Fig 2 PCR amplification of sequence DNA by NL1 and NL4 primer (Lane1: ladder, Lane 2,3,4,5: SKY I.1.2, SKY II.3.2, SKY II.3.1 and SKY III.3.1.)

Table 2 Identification of isolates fungus based on their $28 \mathrm{~S}$ rDNA.

\begin{tabular}{llc}
\hline Isolat Code & \multicolumn{1}{c}{ Identification } & $\begin{array}{c}\text { Highest } \\
\text { similarity (\%) }\end{array}$ \\
\hline SKY I.1.2 & $\begin{array}{l}\text { Fusarium sp NRRL 22354 } \\
\text { NRRL223 }\end{array}$ & 98 \\
SKY III.3.1 & Fusarium sp BOL35 & 100 \\
SKY II.3.2 & Nectria rigidiuscula & 100 \\
SKY II.3.1 & Fusarium sp Vega760 & 96 \\
\hline
\end{tabular}

expected, all PCR products showed only a single visible band about $600 \mathrm{bp}$ on agarose gel electrophoresis (Fig 2). Identification of the endophytic fungi have been conducted from D1-D2 region sequence of $28 \mathrm{~S}$ rDNA. Phylogenetic relationships were inferred based on the sequences of the D1-D2 regions in $28 \mathrm{~S}$ rDNA of four fungal isolates. The phylogenetic analysis showed relationshipswith 31 strains cited from GenBank (Fig 4). Phylogenetic tree indicated that the four fungal isolates consist of three groups, the genera Nectria, Clyndrocladium, and Fusarium with similarity 96-100\%.

Cytotoxicity Assay in vitro with MTT Method on Breast Cancer Cells MCF-7. Cytotoxicity assay of ethyl acetate extract was carried out at level 100 ppm by MTT viability test towards MCF-7 (breast cancer cell). Fig 3 showed that the ethyl acetate extract from secondary metabolites of SKY I,1.2, SKY II.3.2 and SKY III.3.1 (except SKY II.3.1) could inhibit more than $50 \%$ growth of MCF-7 cell at extract concentration $100 \mathrm{ppm}\left(\mu \mathrm{g} \mathrm{mL}^{-1}\right)$ in comparison to the untreated control cells (negative control).

\section{DISCUSSION}

Based on morphological differences, four fungal isolates were obtained in this study and identified using their 28S rDNA sequence (Table 2). In this study, we sequenced about 600 nucleotides from the 5 ' end of the large subunit rDNAs from each isolated fungus and used phylogenetic analyses of these sequences to evaluate species assignments to the various genera. Determination of the D1-D2 regions from 28S rDNA was used and developed by O'Donnell (1996) to classify Fusarium or fungi. This method is widely used to determine other fungi, like the identification of ascomycetous yeasts by Kurtzman (1997), yeast species by Lachance (2003) and black yeast by Ainsle (2007).

In the phylogentic relationship analysis, we compared the rDNA sequences with the sequences 


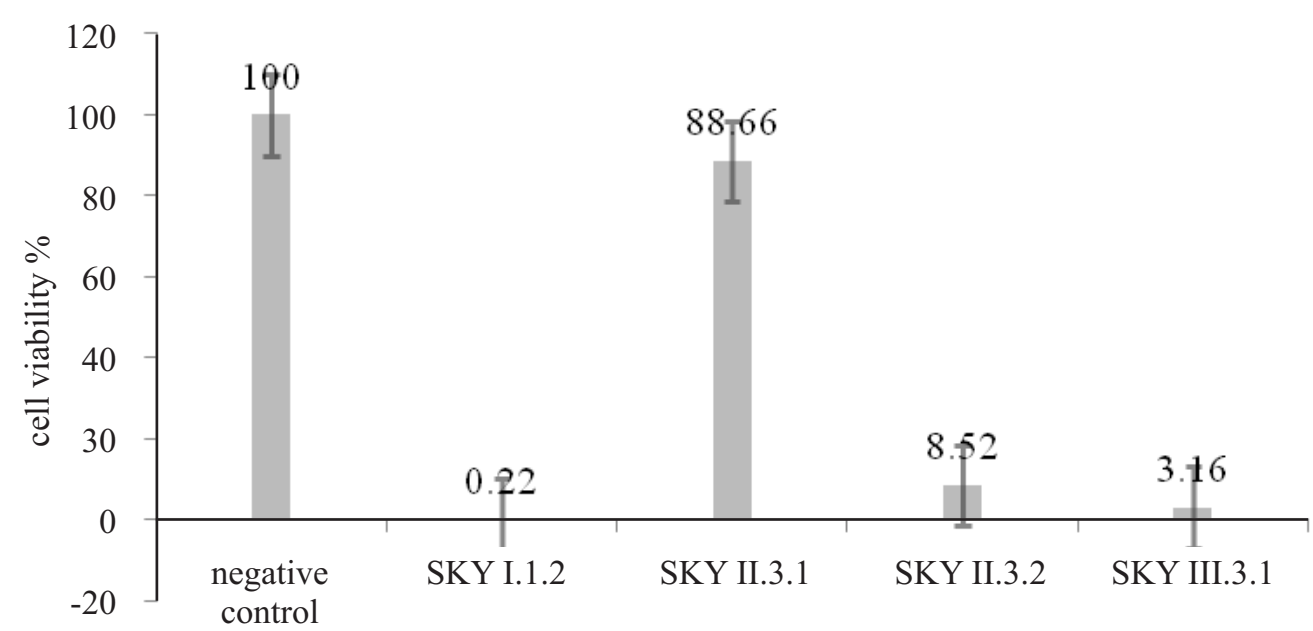

Fig 3 Effect of each ethyl acetate extract (100 ppm) on cytotoxicity in breast cancer cell MCF-7 as determined by the MTT cell viability assay.

ofseven fungal genera of (Acremonium, Phomopsis, Colletotrichum, Clyndrocladium, Acremonium, Nectria and Fusarium) available from the Gene Bank. The results showed that two isolates belongs to the genus Fusarium, and isolate SKY II. 3.2, which was identified as Nectria, showed some genetical similarities with the species Nectria rigidiuscula (Fig 4). SKY II.3.1, although having some similarities with Fusarium sp Vega760, in the phylogenetic analysis was classified as group 5, genus Clyndrocladium. These results are similar to research conducted by Roberta et al (2006) who isolated endophytic fungi from leaves, stems and roots of 110 sweetsop and 90 soursop plants from Pernambuco-Brazil, and were identified as Acremonium (10.34\%), Aspergillus (3.45\%), Chaetomium (3.45\%), Colletotrichum (10.34\%), Cylindrocladium (13.8\%), Fusarium (31.03\%), Glomerella (3.45\%), Nigrospora (6.9\%), Penicillium (6.9\%), and Phomopsis (10.34\%).

Meanwhile, Xiao Lin et al. (2010) had isolated 131 strains of endophytic fungi from the plant Annona squamosa during different seasons in China. Phylogenetic analysis showed that these fungi were distributed in 10 orders and 19 genera. They were mostly in the orders of Diapothales and Hypocreales. This confirmed that the endophytes of sugar apple plants are mainly from Diapothales and Hypocreales orders, in this phylogenetic study the four fungi isolated were of the order Hypocreales. The different distribution patterns of fungal isolates into different orders between Brazil and Indonesia on one side and China on the other hand, confirmed that endophytes highly dependent on environmental conditions where the host lives (Strobel 2003). In this study, we only isolated the endophytic fungi of Anonna squamosa growing in one location (Tangerang, Indonesia).

The ethyl acetate fraction extracts, instead of the butanol extracts as previously conducted by Kumala et al. (2007), were screened for their cytotoxicity. The use of ethyl acetate extracts was intended to facilitate further isolation of single compound compared to the butanol extract, which is more polar.

Sreening of fungal isolates efficacy as anti-cancer was performed in vitro by cytotoxicity assay using MTT method. The MTT test was performed to measure the abilty of extracts at a concentration of $100 \mathrm{ppm}(\mu \mathrm{g}$ $\mathrm{mL}^{-1}$ ) to inhibit the growth of MCF-7 cancer cells. According to Meyer et al. (1982), if an extract has an $\mathrm{LC}_{50}$ less than $1000 \mathrm{ppm}\left(\mu \mathrm{g} \mathrm{mL} \mathrm{L}^{-1}\right)$, it is considered active. although Swanson and Pezzuto (1990) claimed that a compound is considered active, only when it has $\mathrm{LC}_{50}$ less than $20 \mathrm{ppm}$. In this study, the MTT test was carried out at concentrations $100 \mathrm{ppm}$. The isolated fungi was considered potential as anti cancer, if treatment with the ethyl acetate extract showed percentage viability of MCF-7 cells less than $50 \%$, whichmeans that the extract can inhibit growth of MCF-7 cell more than $50 \%$ at concentration extract on $100 \mathrm{ppm}\left(\mu \mathrm{g} \mathrm{mL} \mathrm{L}^{-1}\right)$.

Screening of endophytic fungi as anti-cancer was conducted using extracts of secondary metabolites such as conducted by Kumala et al. (2007) and Karrosi et al. (2009). Meanwhile, Xiao Lin et al. (2010) performed screening based on the sequence of bases from endophytic fungi that have a homologous sequence with primer that produces polyketide synthase (PKS). The active anti-cancer compounds from the host are polyketides that are extracted from the seed of sugar 


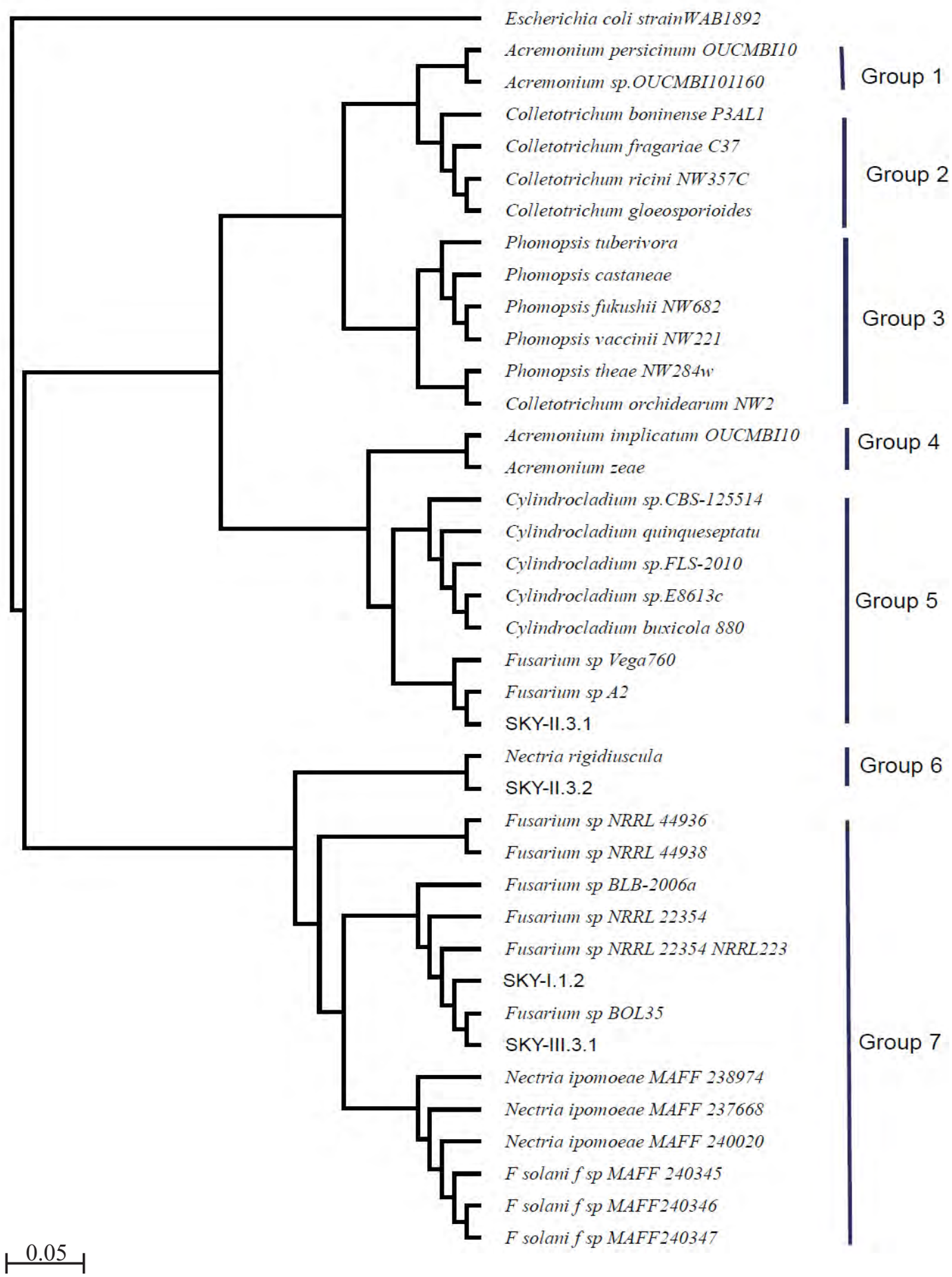

Fig 4 Phylogenetic tree of endophytic fungal isolates from twigs Annona squamosa.

apple fruit, so that endophytic fungi are expected to have the PKS gene that can produce the same polyketide compounds as produced by their host plant. However, according to Tan and Zou (2001), anti-cancer compounds from endophytic fungi is not only polyketide, but could also be alkaloids, terpenoids, or phenol. This is relevant with the results of investigation by $\mathrm{Lu}$ et al. (2008), who managed to isolate a tenmembered lactone, namely phomolide C, 1-methoxy-8Hydroxy-9.10-anthraquinone, 1.8-dihydroxy-anthra- quinine-9, 10 (1.8. DHA), CytoSpo-rone $\mathrm{C}$ and altiloxin A from Phomopsis sp.B27, an endophytic fungal strain of Annona squamosa.

Based on the results of cytotoxicity assays on MCF7 breast cancer cells (Fig 3), endophytic fungal isolates of SKY I.1.2, II.3.2 and III.3.1 are potential as producers of anti-cancer by fermentation. The potential compounds had been isolated using chromatography technique. To further continue this study, we plan to perform cytotoxicity assays of the isolated compounds 
on MCF-7 and CHO (normal cell) cell lines, in also comparison to the commercially available anti-cancer drugs (Cisplatin or Doxo) as positive control. If the $\mathrm{LC}_{50}$ of the isolated compounds to MCF-7 and $\mathrm{CHO}$ cell line is not significant compared to the positive control, then, they are potential as anti-cancer agents.

\section{REFERENCES}

Ainslie EF, Cameron RC. 2007. Symbiotic complexity: discovery of a fifth symbiont in the attine ant -microbe symbiosis. Biol Lett. 3(5): 501-504. doi:10.1098/rsbl. 2007.0253.

Chih CL, Yang CL. 2008. Mono-tetrahydrofuran Annonaceous acetogenins from Annona squamosa as Cytotoxic Agents and Calcium Ion Chelators. J Nat Prod. doi:10.1021/np0704957.

Ebel R. 2006. Secondary metabolites from marine-derived fungi. In: Proksch P, Müller WEG, editors. Frontiers in marine biotechnology. Norwich: Horizon Bioscience Pr. p 73-144.

Guang XZ, Chen RY, Zhang YC, Yu D Q. 2000. Calamistrin $\mathrm{E}$, the first Annonaceous Acetogenin with double bond in aliphatic chain from genus Uvaria. Chin Chem Lett . 11(4):341-342.

Hai H X, Xiao Y W, Wang J D, Liu, Yang RZ. 2003. A new cytotoxic acetogenin from the seeds of Annona squamosa. Chin Chem Lett. 14(6):588-590.

Hollingworth RM, Ahammadsahib KI, Gadelhak G, and McLaughlin JL. 1994. New inhibitors of complex I of the mitochondrial electron transport chain with activity as pesticides. Biochem Soc Trans. 22(1):230-233.

Joseph B, Priya RM. 2011. Bioactive compounds from endophytes and their potential in pharmaceutical effect: a review. Am J Biochem Mol Biol. (8):291-309. doi: 10.3923/ajbnb.2011.291.309.

Karrosi AT, Poniah S, Linar Z, Udin. 2009. Anti breast cancer activity of ethyl acetat extract of fermentation broth employing endophitic Taxus sumatrana isolates. J Kimia Terapan Indonesia. 11(1):22-25.

Kumala S, Utji R, Pratiwi S, Kardono LBS. 2007. Isolation of endophytic fungi from Brucea javanica L.(Merr.) and cytotoxic evaluation of their n-butanol extract from fermentation broth. Pak J Biol Sci. 9: 825-832. doi: 10.3923/jm.2007.625.631.

Kurtzman CP, Robnet CJ. 1997. Identification of clinically important Ascomycetous Yeasts based on nucleotide divergence in the 59 end of the large-ubunit (26S) Ribosomal DNA gene. J Clin Microbiol. 35(5):12161223.

Lachance MA, Daniel HM, Meyer W, Prasad, Gautam SP, Boundy-Mills K. 2003. The D1/D2 domain of the largesubunit rDNA of the yeast species Clavispora lusitaniae is unusually polymorphic. FEMS Yeast Res. 4:253-258. doi:10.1016/S1567-1356(03)00113-2.
Landolt Jl, Ahammadsahib KI, Hollingworth RM. 1995. Determination of structure-activity relationships of Annonaceous acetogenins by inhibition of oxygen uptake in rat liver mitochondria. Chem Biol Interact. 98(1):1-13.

Lu CH, Xiao L, Shen YM. 2008. One new ten-membered lactone from phomopsis sp. B27, an endophytic fungus of Annona squamosa. Chin J Nat Med. 6: 0391-0394. doi: 10.3724/SP.J.1009.2008.00391.

McLaughlin J1, David CH, inventors; Purdue Research Foundation, assignee. 2001 June 5. Selectively cytotoxic acetogenin compounds. United States Patent. US 6,242,483.

Meyer BN, Ferrigni NR, Pulman JE, Jacobson, Nicholas DE, McLaughlin. 1982. Brine Shrimp: a convenient general bioassay for active plant constituents. Plant Med. 45:31-34

O'Donnell K. 1996. Progress towards a phylogenetic classification of Fusarium. Sydowia 48(1): 57-70.

Roberta LOS, Jaqueline SL, Barbosa E, Cavalcante. 2006. Fungos endofíticos em Annona spp.: isolamento, caracterizaçãoenzimática e promoção do crescimento em mudas de pinha (Annona squamosa L.) [Endophytic fungi of Annona spp.: isolation, enzymatic characterization of isolates and plant growth promotion in Annona squamosa L. seedlings]. Acta Bot Bras. 20(3): 649-655. doi:10.1590/S0102-330620060003 00015.

Rusman Y. 2006. Isolation of secondary metabolites from sponge-assosiated and plant-derived endophtic fungi. Gottingen: Cuvillier Verlag Gottingen.

Strobel GA, Daisy B. 2003. Bioprospecting for microbial endophytes and their natural products. Microbiol Mol Biology Rev. 67(4):491-502. doi : 10.1128/MMBR.67. 4.491-502.2003.

Swanson SM, Pezzuto JM. 1990. Bioscreening technique for cytotoxic potential and ability to inhibit macromolecule biosynthesis. In Thompson EB, editor. Drug bioscreening; drug evaluation techniques in pharmacology. New York: WCH Publishers Inc. 273297.

Wani MC, Taylor HL, Aal ME, Goggon P, McPhail AT. 1971. Plant Antitumor-agent IV, The Isolation and structure of taxol, a novel antileukemic and anti-tumor. J Am Chem Soc. 9:2325-2327.

Wu YC, inventor; Advpharma, Inc, assignee. 2007 May 29. Cytotoxic annonaceous acetogenins from Annona muricata. United States Patent. US 7,223,792 B2.

Tan RX, Zou WX. 2001. Endophytes: a rich source of functional metabolites. Nat Prod Rep. 18 (4): 448-459. doi : 10.1039/B100918O.

Xiao LY, Huang J, Zheng ZH, Su WJ, Qian XM, Shen YM. 2010. Endophytes from the pharma-ceutical plant, Annona squamosa: isolation, bioactivity, identification and diversity of its polyketide synthase gene. Fungal Divers. 41 (1): 41-51. doi: 10.1007/s13225-010-0017-5. 